\title{
KONSEP WELLFARE STATE DI INDONEISA
}

\author{
Winda Roselina Effendi \\ Ilmu Pemerintahan Fakukltas Ilmu Sosial dan Ilmu Politik \\ Universitas Kepulauan Riau Batam \\ winda.effendis@gmail.com
}

\begin{abstract}
Walfare State concept born in the era of the 20th century as a correction of the development of the concept of the country as night watchman, the phenomenon of economic capitalism that gradually leads to lameness in the distribution of sources of prosperity. In the Walfare State concept, the state is required to extend its responsibility to the socio-economic problems facing the people. The functions of the state also include activities that were previously beyond the scope of state functions, such as extending the provision of social services to individuals and families in specific matters, such as social security. The role of the state can not be separated with Welfare State because the state that plays a role in managing the economy which includes the responsibility of the state to ensure the availability of basic welfare services in certain levels. Welfare State does not reject the existence of a capitalist market economy system but believes that there are elements in the public order that are more important than market objectives and can only be achieved by controlling and limiting the operation of such market mechanisms.
\end{abstract}

Keywords: walfare state, country, economic system

\begin{abstract}
Abstrak
Konsep Walfare State yang lahir di era abad ke-20 sebagai koreksi berkembangnya konsep negara sebagai penjaga malam, gejala kapitalisme perekonomian yang secara perlahanlahan menyebabkan terjadinya kepincangan dalam pembagian sumber-sumber kemakmuran bersarma. Dalam konsep Walfare State, negara dituntut untuk memperluas tanggung jawabnya kepada masalah-masalah sosial ekonomi yang dihadapi rakyat. Fungsi negara juga meliputi kegiatan-kegiatan yang sebelumnya berada diluar jangkauan fungsi negara, seperti memperluas ketentuan pelayanan sosial kepada individu dan keluarga dalam hal-hal khusus, seperti social security, kesehatan. Peran negara tidak bisa dipisahkan dengan Welfare State karena negara yang berperan dalam mengelola perekonomian yang yang di dalamnya mencakup tanggung jawab negara untuk menjamin ketersediaan pelayanan kesejahteraan dasar dalam tingkat tertentu. Welfare State tidak menolak keberadaan sistem ekonomi pasar kapitalis tetapi meyakini bahwa ada elemen-elemen dalam tatanan masyarakat yang lebih penting dari tujuan-tujuan pasar dan hanya dapat dicapai dengan mengendalikan dan membatasi bekerjanya mekanisme pasar tersebut.
\end{abstract}

Kata Kunci: walfare state, negara,sistem ekonomi 


\section{A. Pendahuluan}

Pembangunan kesejahteraan sosial di Indonesia sesungguhnya mengacu pada konsep negara kesejahteraan. Pancasila sebagai dasar negara menekankan prinsip keadilan sosial dan secara eksplisit konstitusinya pada pasal 27 dan 34 UUD 1945, mengamanatkan tanggungjawab pemerintah dalam pembangunan kesejahteraan sosial. Namun demikian, amanat konstitusi tersebut belum dipraktekan secara konsekuen. Baik pada masa Orde Baru maupun era reformasi saat ini, pembangunan kesejahteraan sosial baru sebatas jargon dan belum terintegrasi dengan strategi pembangunan ekonomi.

Dalam Negara modern atau Negara kesejahteraan, mempunyai kewajiban untuk menyelenggarakan kesejahteraan rakyatnya. Dengan demikian pemerintah dituntut untuk bertindak menyelesaikan segala aspek persoalan yang menyangkut kehidupan warga negaranya. Konsep Walfare State yang lahir di era abad ke-20 sebagai koreksi berkembangnya konsep negara sebagai penjaga malam, gejala kapitalisme perekonomian yang secara perlahan-lahan menyebabkan terjadinya kepincangan dalam pembagian sumber-sumber kemakmuran bersarma. ${ }^{1}$ Akibatnya timbul jurang kemiskinan yang menunjukkan kecenderungan semakin menajam, yang sulit dipecahkan oleh negara yang difungsikan secara minimal. Negara diangap tidak dapat melepaskan tanggung jawabnya untuk meningkatkan kesejahteraan masyarakat. Munculnya aliran sosialisme yang menentang individualisme dan liberalisme yang dianggap sebagai sebab rnunculnya kapitalisme yang menindas rakyat miskin dan bahkan menciptakan kemiskinan itu sendiri. Karena itu, atas pengaruh sosiailisme ini, muncul konsepsi baru mengenai negara sebagai penjaga malam, menjadi walfare State.

Dalam konsep Walfare State, negara dituntut untuk memperluas tanggung jawabnya kepada masalah-masalah sosial ekonomi yang dihadapi rakyat. Fungsi negara juga meliputi kegiatan-kegiatan yang sebelumnya berada diluar jangkauan fungsi negara, seperti memperluas ketentuan pelayanan sosial kepada individu dan

\footnotetext{
1 Jurnal Hukum, 2005, Konsep Negara Kesejahteraan pra Kemerdekaan RI,vol xv, no. 3.
} 
keluarga dalam hal-hal khusus, seperti social security, kesehatan. Globalisasi dapat dipahami sebagai perubahan-perubahan dalam bidang ekonomi dan sosial yang berkombinasi dengan pembentukan hubungan regional dan global yang unik, yang lebih ekstensif dan intensif dibandingkan dengan periode sebelumnya, yang menantang dan membentuk kembali komunitas politik, dan secara spesifik, negara modern melibatkan sejumlah perkembangan yang dapat dipikirkan sebagai sesuatu yang mendalam dan melibatkan suatu transformasi struktural. ${ }^{2}$

Telaah hukum terhadap konsep ini selanjutnya dielaborasi hingga berdimensi ideolgi, demokrasi dan politik. Namun, globalisasi merubah konsep kesejahteraan dengan definisi awal yang mengenal welfare state sebagai bentuk perbaikan setelah perang yang menghadirkan tuntutan bagi negara untuk lebih mengedepankan fokus kebijakan ke arah kesejahteraan sosial. Konsep Welfare ini menggambarkan sistem dimana negara mengambil tanggung jawab penuh terhadap kesejahteraan masyarakatnya. ${ }^{3}$

\section{B. Isi dan Pembahasan}

\section{Teori Welfare State}

Negara Kesejahteraan, Welfare State bertujuan mewujudkan kesejahteraan umum. Negara adalah alat yang dibentuk rakyatnya untuk mencapai tujuan bersama, yaitu kemakmuran dan keadilan sosial. Menurut Kranenburg teori Welfare State bukan sekadar memelihara ketertiban hukum, melainkan juga aktif mengupayakan kesejahteraan warganya. Kesejahteran pun meliputi berbagai bidang yang luas cakupannya, sehingga selayaknya tujuan negara itu disebut secara plural yaitu tujuan-tujuan negara

Selain itu menurutnya bahwa upaya pencapaian tujuan-tujuan negara itu dilandasi oleh keadilan secara merata, seimbang. ${ }^{4}$ Peran negara tidak bisa dipisahkan dengan Welfare State karena negara yang berperan dalam mengelola perekonomian yang yang di dalamnya mencakup tanggung jawab negara untuk

2 Budi Winarno,Globalisasi dan Masa Depan Demokrasi, Pengajar Ilmu Hubungan Internasional , Universitas Gadjah Mada

3 Linda Hantrais dalam Hay Collin. 2007, Walfare Policy, New York: Oxford University Press.

4 Kranenburg, R. dan Tk. B. Sabaroedin. 1989, Ilmu Negara Umum. Cetakan Kesebelas.

Jakarta: Pradnya Paramita. 
menjamin ketersediaan pelayanan kesejahteraan dasar dalam tingkat tertentu. Welfare State tidak menolak keberadaan sistem ekonomi pasar kapitalis tetapi meyakini bahwa ada elemen-elemen dalam tatanan masyarakat yang lebih penting dari tujuan-tujuan pasar dan hanya dapat dicapai dengan mengendalikan dan membatasi bekerjanya mekanisme pasar tersebut.

Negara dapat tergolong sebagai Welfare State dapat diamati melalui beberapa karakter umum tertentu yaitu, lebih dari setengah pengeluaran negara tersebut ditujukan untuk kebijakan sosial atau tanggung jawab untuk penyediaan kesejahteraan yang komprehensif dan universal bagi warganya, adanya komitmen jangka panjang yang dibuat dimana memiliki seperangkat program pemerintah yang bertujuan untuk menjamin kesejahteraan untuk menghadapi kemungkinan yang akan dihadapi dalam modernitas, individualisasi, dan masyarakat yang terindustrialisasi selanjutnya, negara menjadi negara yang tanpa kehilangan posisi pemegang tanggung jawab utamanya, mampu mengkombinasikan tenaga dari berbagai pihak sebagai organisasi sosial, pihak independen, voluntary dalam menyediakan perlindungan kesejahteraan bagi masyarakat. ${ }^{5}$

Welfare State pada mulanya dimulai dari model pembangunan dapat digolongkan menjadi dua yang saling bertentangan yaitu demokrasi sosial klasik dengan ciri besarnya keterlibatan negara di dalam kehidupan sosial dan ekonomi, dominasi negara terhadap civil society, kolektivitas, terbatasnya peran pasar, pemaksimalan pemberdayaan SDM, egalitarianisme yang kuat, negara kesejahteraan yang aktif secara luas melindungi rakyatnya, dan Internasionalis medan neoliberalisme. Melihat neoliberalisme dengan ciri minimnya peran negara, civil society yang berkembang fundamentalisme pasar bebas, individualisme, negara kesejahteraan hanya sebagai jaring pengaman namun kesamaan keduanya sama-sama memiliki rendahnya kesadaran terhadap kekuasaan lingkungan dan pandangan linier terhadap modernisasi. ${ }^{6}$

5 Collin Hay, 2006, The State Theory and Issues, New York : Palgreve Macmillan, Chapter Intrudusing.

6 Giddens Anthony, 1999 , The Third Way, Jakarta: Gramedia PustakaUtama 
Dilema dari kedua model ini yaitu, munculnnya globalisasi yang merupakan rentangan proses yang kompleks yang digerakkan oleh berbagai pengaruh politis dan ekonomi dengan masalah ketergantungan menyangkut transformasi waktu dan ruang dalam kehidupan. Selanjutnya individualisme sikap hidup yang menjauh dari pola komunalisme dan merupaskan ancaman bagi solidaritas dan mengenai pelaku politik utama dan peran merupakan suatu permasalahan yang juga sulit untuk dipecahkan dalam hal ini peran pemerintah, partai-partai politik, dan pelaku politik lain (NGO) di dalam era globalisasi sekarang, tentu harus mengalami perkembangan. Terakhir isu perusakan lingkungan merupakan isu yang tidak diperhatikan oleh sosial klasik maupun neoliberal dalam melaksanakan pembangunan. Konsep pembangunan yang berwawaskan lingkungan menjadi perdebatan. Oleh karenanya Giddens mengemukakan jalan alternatif dari lima dilema dengan mempertahankan inti keperdulian pada keadilan sosial dan sekaligus mengakui bahwa rentang masalah yang lepas dari sekedar perbedaan antara justru lebih luas dari sebelumnya. Politik "jalan ketiga" juga bermakna mencari hubungan baru antara sosial klasik dan neoliberalis. Jalan ketiga juga tidak dapat ditafsirkan sebagai sekedar pilihan antara sosialisme atau kapitalisme, antara intervensi negara atau pasar bebas, namun merupakan jalan keluar untuk menemukan alternatif di dalam menghadapi dilema yang ada dengan nilai-nilai persamaan, perlindungan terhadap yang lemah kebebasan sebagai otonomi, tidak ada individualisme di dalam komunitas, terciptanya civil society, pluralitas kosmopolitan dan konservatisme filosofis.

\section{Konsep Walfare State Indonesia}

\section{a. Negara dalam Walfare State}

Negara terbentuk atas proses pemenuhan unsur kepada pemenuhan unsur lainya. Penyempurnaan unsur negara ini menyebabkan kapasitasnya sebagai etentitas politik yang memiliki subyek hukum. Proses terjadinya negara secara primer maupun sekunder berhubungan erat dengan syarat-syarat adanya penduduk, wilayah dan pemerintah sebagai unsur pokok yang harus dipenuhi 
untuk eksistensi keberadaanya. ${ }^{7}$ Unsur Sekunder pengakuan atas adanya negara oleh internasional. Melihat teori negara didalam negara kesejahteraan bahwa Indonesia, dalam konsep kesejahteraan merujuk pada konsep pembangunan kesejahteraan sosial, yakni serangkaian aktivitas yang terencana dan melembaga yang ditujukan untuk meningkatkan standar dan kualitas kehidupan manusia. Sebagai sebuah proses untuk meningkatkan kondisi sejahtera, istilah 'kesejahteraan' sejatinya tidak perlu pakai kata 'sosial' lagi, karena sudah jelas menunjuk pada sektor atau bidang yang termasuk dalam wilayah pembangunan sosial. $^{8}$

Walfare state sangat erat kaitannya dengan kebijakan sosial (social policy) yang di banyak negara mencakup strategi dan upaya-upaya pemerintah dalam meningkatkan kesejahteraan warganya, terutama melalui perlindungan sosial (social protection) yang mencakup jaminan sosial (baik berbentuk bantuan sosial dan asuransi sosial), maupun jaring pengaman sosial (social safety nets). Negara Indonesia seringkali disebut sebagai negara yang mengusung gagasan Negara kesejahteraan (walfare State) hal ini karena di dalam pembukaan UUDRI 1945 terdapat salah satu tujuan negara yang mengekspresikan gagasan Negara kesejahteraan itu. Gagasan Negara kesejahteraan sebagai sebuah konsep, bukan terlahir dari sebuah ihtiar pendek. Ditilik dari perspektif sejarah, Walfare State hadir dalam bayang-bayang pergumulan dua ideologi ekstrim yakni, individualisme dan kolektivisme. Dalam perkembangan selanjutnya gagasan Negara kesejahteraan berkembang menjadi beberapa konsep dengan menampilkan beberapa varian. ${ }^{9}$ Meskipun konsep negara kesejahteraan tidak tercantum secara normatif (tegas) dalam UUD 1945, bukan berarti dapat disimpulkan bahwa Indonesia bukan sebagai negara yang mengusung konsep negara kesejahteraan.

Ditinjau dari sejarah mencatat bahwa pada tanggal 1 Maret 1945, Pemerintah Jepang meresmikan terbentuknya Badan Penyelidik Usaha-usaha

\footnotetext{
7 Hendra Nurtjahjo, 2004, Ilmu Negara Republik Indonesia(pengembangan teori bernegara dan suplemen),Pusat Studi Hukum Tata Negara, hal 32

8 Edi Suharto, 2006, Negara Kesejahteraan dan Reinventing Depsos, WalfareStateDeptSos.

9 Tavip Muhammad, 2013, Skripsi Dinamika Negara Kesejahteraan Indonesia Dalam UndangUndang Dasar 1945: Malang: Pasca Sarjana Hukum, Universitas Brawijaya.
} 
Persiapan Kemerdekaan Indonesia (BPUPKI). Tugas badan ini adalah untuk mempelajari dan menyelidiki hal-hal penting yang berhubungan dengan segi-segi politik, ekonomi, tata pemerintahan dan lain-lainnya, yang dibutuhkan dalam usaha pembentukan negara Indonesia merdeka. Dengan tercetusnya Pancasila sebagai dasar negara itulah yang kemudian pokok pikiran Pancasila menjadi dasar bahwa Indonesia adalah negara kesejahteraan.

\section{b. Hubungan Partai Politik dan Walfare State dalam Negara Pancasila}

Partai Politik adalah sebuah organisasi untuk memperjuangkan nilai atau idiologi tertentu melalui penguasa struktur kekuasaan dan kekuasaan itu diperoleh melalui pemilu. Disimpulkan bahwa pertama, partai politik merupakan sebuah organisasi, kedua partai politik adalah instrumen perjuangan nilai atau idiologi. Partai Politik, bukan birokrasi, pengadilan atau parlemen menjadi penanda dan spasi penting transformasi sistem politik klasik ke metode berpolitik modern. Keberadaan partai politik mengubah relasi antara rakyat dan penguasa, yaitu dari yang semula mendiskualifikasi rakyat menjadi rakyat sebagai aktor dan proses penting dalam relasi itu. Kehadiran partai politik juga telah mengubah sirkulasi elit politik dari tertutup menjadi terbuka. Dengan partai politik jabatan-jabatan politik yang semula privellage kelompok sosial tertentu menjadi dapat diakses dari dan oleh semua kalangan masyarakat tanpa melihat kelas dan stratifikasi sosial. ${ }^{10}$ Saat ini sangat sedikit negara yang mengabaikan relevansi partai politik dalam kehidupan demokrasinya. Hal ini dikarenakan absenya partai politik dari kancah politik yang akan menghadirkan dua kemungkinan. Pertama, sebuah negara yang akan dikuasai oleh rezim-rezim dinasti tradisional, kedua, negara yang dikuasai oleh rezim-rezim militer dikarenakan militer adalah entitas modern yang paling solid dan terorganisir secara baik. ${ }^{11}$

Pancasila sebagai idiologi Indonesia dalam arti netral sebagai sistem berfikir dan tata nilai dari suatu kelompok. Idiologi dalam arti netral ditemukan

\footnotetext{
${ }^{10}$ Sigit Pamungkas, 2011, Partai Politik: Teori dan Praktik di Indoneisa, Institute for Democracy and Welfarism: Yogyakarta.

${ }_{11}$ Ibid;
} 
dalam idiologi negara yaitu pembahasan Pancasila. ${ }^{12}$ Yang apabila dikaitkan dengan Walfare State adanya dukungan dari elit sebagai upaya kesejahteraan untuk rakyatnya. Tipe idiologi terdiri dari Pertama, ajaran atau pandangan dunia yang menentukan tujuan dan norma politik dan sosial, yang ditasbihkan sebagai kebenaran yang tidak bisa dipersoalkan melainkan, harus diterima sebagai suatu yang harus dipatuhi. Kedua, Tidak hanya menentukan kebenaran nilai dan prinsip dasar saja, tetapi menentukan hal-hal yang bersifat konkret operasional yang bersumber dari dari pikiran elit.

Melihat peran Partai Politik yang seharusnya menjadi salah satu kendaraan mengusung Walfare State namun, dalam prakteknya tidak secara serta merta menjunjung idiologi yang telah menjadi dasar negara, terlihat adanya krisis kepercayaan masyarakat terhadap partai politik semakin menguat karena menurut masyarakat, partai politik tidak bermanfaat positif untuk perbaikan kehidupan bangsa dan negara, justru merusak tatanan hukum dan demokrasi serta menciptakan kondisi politik yang tidak beraturan. Krisis kepercayaan ini dilatarbelakangi adanya kinerja buruk partai politik yang ditunjukkan melalui banyaknya kader partai politik terlibat kasus korupsi, kader partai tidak berpihak kepada rakyat dan menjadikan Pancasila sebagai dasar kepentingan dan kesejahteraan rakyat namun, merubah idiologi untuk kepentingan golongan. Nilai-nilai demokrasi seperti keadilan, partisipatif, pemerataan, dan taat hukum dalam upaya mewujudkan Walfare State harus dijadikan sebagai pedoman dalam bersikap dan menentukan kebijakan publik tapi praktenya Partai Politik tidak menjadikan nilai-nilai idiologi demokrasi Pancasila sebagai landasan atau pedoman dalam berpolitik.

Sehubungan dengan apa yang dikatakan Giddens tentang Negara mengenai Walfare State dan hubungan dengan Pancasila sebagai dasar negara Indonesia, Indonesia telah mempunyai pijakan dasar yang baik untuk mewujudkan kesejahteraan karena sejalan dengan apa yang dikemukakan Giddens. Pancasila sendiri memiliki perbedaan dengan sistem kapitalis-liberal

12 Asshiddiqie Jimly, Idiologi Pancasila dan Konstitusi,Mahkama Konstitusi RI. 
maupun sosialis-komunis karena, Pancasila mengakui dan melindungi baik hakhak individu dan masyarakat baik dalam ekonomi maupun politik. Dengan demikian idiologi Indonesia mengakui secara selaras baik kolektive maupun Individualisme. Demokrasi yang dikembangkan, bukan demokrasi politik semata seperti liberalis-kapitalis, tetapi juga demokrasi ekonomi secara bersama. ${ }^{13}$

Berarti Pancasila sebagai dasar negara telah memiliki pijakan untuk mewujudkan Walfare State namun, Fungsi Partai Politik yang seharusnya sebagai penyalur kontribusi pada negara adalah membuat kebijakan tentang apa yang patut dan baik dibuat oleh negara, dengan berpijak terhadap idiologi dilain sisi, pengerak serta menjadi motor menuju kesejahteraan belum secara nyata memperlihatkan fungsi sebagai motor pengerak regulasi keterbukaan yang telah diberikan pemerintah dengan menghadirkan dan menciptakan relasi yang baik untuk tujuan-tujuan tertentu dalam berbagai hal termasuk menciptakan kesejahteraan negara.

\section{c. Walfare State, dalam kemiskinan dan ketidakadilan Indonesia}

Indonesia sebagai Negara yang mayoritas islam dengan sumberdaya alam yang baik seharusnya bisa dengan mudah dalam mewujudkan negara kesejahteraan namun kenyataannya, Indonesia adalah negara yang masih menghadapi persoalan kesejahteran yang serius. Ironisnya, kontribusi negara sebagai institusi yang seharusnya memiliki peran penting dalam mensejahterakan warganya, ternyata masih jauh dari harapan. Berbagai masalah ekonomi, sosial dan politik di Indonesia seringkali disebabkan oleh kegagalan negara dalam memainkan perannya dengan baik. Seakan-akan negara tidak pernah dirasakan kehadirannya terutama oleh mereka yang lemah atau dilemahkan atau dalam kata lainyang miskin atau dimiskinkan.

Mewujudkan kesejahteraan menuju kondisi sejahtera (well-being) biasanya menunjuk pada istilah kesejahteraan sosial (social welfare) sebagai

13 Ibid; 
kondisi terpenuhinya kebutuhan material dan non-material. Midgley dalam Edi Suharto mendefinisikan kesejahteraan sosial sebagai a condition or state of human well-being dimana, kondisi sejahtera terjadi manakala kehidupan manusia aman dan bahagia karena kebutuhan dasar akan gizi, kesehatan, pendidikan, tempat tinggal, dan pendapatan dapat dipenuhi serta manusia memperoleh perlindungan. ${ }^{14}$ dari resiko-resiko utama yang mengancam kehidupan manusia itu sendiri. Melihat apa yang menjadi tujuan Walfare State berusaha untuk meningkat kemakmuran masyarakatnya. Ini dapat dilihat dari upaya negara membangun sistem kesejahteraan sosial yang diharapkan dapat menjadi basis untuk mengurangi kemiskinan, membangun ekonomi masyarakat dan melindunginya dari ketidakadilan pasar.

Dasar pemikiran negara kesejahteraan ini dapat ditelusuri dari pemikiran John M Keynes Dalam liberalisme dapat dirumuskan konsep negara proporsional, di mana negara diperbolehkan melakukan intervensi terhadap pasar terutama dalam hal kesejahteraan. ${ }^{15}$ Keynes melalui bentuk negara kesejahteraan menunjukkan bahwa konsep negara proporsional tidak bertentangan dengan kebebasan individu yang merupakan nilai utama dari liberalisme serta bisa menjadi dasar intervensi negara terhadap pasaryang mengkritik penerapan kebijakan laissez faire yang justru berdampak tidak baik kepada masyarakat. Menurutnya, agar dapat meminimumkan implikasi negatif mekanisme pasar tersebut, negara harus melakukan intervensi dan melindungi warganya, terutama untuk menciptakan sistem ekonomi yang berkeadilan. Prinsip negara kesejahteraan ini, dalam banyak hal memang bertentangan dengan pemikiran liberalisme dan neoliberalisme yang mengutamakan segala sesuatunya ada dalam mekanisme pasar.

Kesejahteraan Indonesia menurut survei Litbang (73\%) merasakan bahwa pemenuhan kebutuhan sehari-hari semakin berat, sebanyak $21 \%$ responden merasakan sama saja, dan hanya $6 \%$ yang merasakan semakin ringan. Ketika

14 Edi Suharto, 2006, Negara Kesejahteraan dan Reinventing Depsos, WalfareStateDeptSos.

15 Nugroho, Anindya Lintang,2011, Konsep negara proporsional John Maynard Keynes sebagai dasar intervensi negara terhadap pasar,Program Studi Filsafat, Universitas Indonesia. 
ditanyakan apakah sekarang ini mendapatkan pekerjaan baru dirasakan semakin sulit atau semakin mudah, sebagian besar responden (89\%) merasakan sekarang makin sulit mencari pekerjaan baru, sebanyak 5\% responden merasakan sama saja, $4 \%$ merasakan makin mudah; dan 2\% tidak tahu. Hasil survei ini tidak berbeda dengan laporan mengenai Indeks Pembangunan Manusia (IPM) untuk tahun 2007/2008 dari United Nations Development Programme (UNDP). Peringkat IPM Indonesia tahun 2007 berada di urutan 107 dari 177 negara. Hingga saat ini, jumlah orang miskin di Indonesia masih sangat mencemaskan. Pada tahun 2007, jumlah penduduk miskin adalah 37,17 juta orang atau $16,58 \%$ dari total penduduk Indonesia. ${ }^{16}$

Melihat sisi lain dari kasus keinginan Pemerintah Indonesia dalam menaikkan harga BBM ini adalah mengikuti mekanisme pasar sesuai dengan pemikiran neoliberalisme. Namun, dari sisi lain, dana lebih dari kenaikan BBM ini sebenarnya dapat digunakan sepenuhnya untuk meningkatkan kesejahteraan masyarakat melalui subsidi kepada masyarakat bawah. Dalam hal ini, sebenarnya pemerintah sedang berusaha bersikap moderat menyeimbangkan kebijakan negara kapitalis yang diamalkannya dan mewujudkan negara kesejahteraan. Namun, sikap moderat ini juga belum sesuai kondisi riil yang hendak diwujudkan dalam jangka pendek dan jangka panjang untuk mengurangi kemiskinan di Indonesia.

\section{Penutup}

Kesejahteraan merupakan sebuah bentuk nyata yang diinginkan oleh setiap masyarakat diberbagai belahan negara belahan dunia, termasuk Indonesi. Melihatkondisi riil Indonesia yang masih jauh dari kesejahteraan yang sebenarnya telah menjadi dasar negara yaitu Pancasila ternyata sangan bertolak belakang dengan kenyataanya. Mengapa demikian? Sebelum adanya Walfare State yangseperti dikatakan Giddens, Indosia telah lebih jauh mengusung dan menjadikankesejahteraan sebagaidasar negara. Dan demokrasi sebenarnya telah memberikan jalan akan perjuangan untuk memberikan kebebasan dan

16 Ibid; 
menciptakan kesejahteraan untuk rakyat dalam segi ekonomi, hukum,sosial dan politik.

Catatan untuk Indonesia untuk dapat mewujudkan kesejahteraan menurut Collin yaitu lebih dari setengah pengeluaran negara tersebut ditujukan untuk kebijakan sosial atau tanggung jawab untuk penyediaan kesejahteraan yang komprehensif dan universal, adanya komitmen jangka panjang yang dibuat dimana memiliki seperangkat program pemerintah yang bertujuan untuk menjamin kesejahteraan untuk menghadapi kemungkinan yang akan dihadapi dalam modernitas, individualisasi, dan masyarakat yang terindustrialisasi selanjutnya, negara tanpa kehilangan posisi pemegang tanggung jawab utamanya, mampu mengkombinasikan tenaga dari berbagai pihak sebagai organisasi sosial, pihak independen, voluntary dalam menyediakan perlindungan kesejahteraan bagi masyarakat.

Hal inilah yang belum diperjuangkan Indonesia secara serius karena masih banyaknya kepentingan-kepentingan golongan yang menjadi catatan hitam Indonesia disamping merangkul berbagai organisasi sosial, pihak independen, maupun voluntary untuk saling bekerjasama. Kranenburg teori Welfare State bukan sekadar memelihara ketertiban hukum, melainkan juga aktif mengupayakan kesejahteraan warganya. Kesejahteran pun meliputi berbagai bidang yang luas cakupannya, sehingga selayaknya tujuan negara itu disebut secara plural yaitu tujuan-tujuan negara. Selain itu menurutnya bahwa upaya pencapaian tujuantujuan negara itu dilandasi oleh keadilan secara merata, seimbang. Pertanyaan selanjutnya, sudah sejauh mana realisasi Pancasila sebagai dasar negara untuk mewujudkan kesejahteraan di Indonesia? 


\section{Daftar Pustaka}

Sigit Pamungkas, 2011, Partai Politik: Teori dan Praktik di Indoneisa, Institute for Democracy and Welfarism: Yogyakarta

Linda Hantrais dalam Hay Collin. 2007, Walfare Policy, New York: Oxford University Press.

Kranenburg, R. dan Tk. B. Sabaroedin. 1989, Ilmu Negara Umum. Cetakan Kesebelas. Jakarta: Pradnya Paramita.

Collin Hay, 2006, The State Theory and Issues, New York : Palgreve Macmillan, Chapter Intrudusing.

Giddens Anthony, 1999 , The Third Way, Jakarta: Gramedia PustakaUtama

Jurnal Hukum, 2005, Konsep Negara Kesejahteraan pra Kemerdekaan RI,vol xv, no. 3.

Budi Winarno, Globalisasi dan Masa Depan Demokrasi,Pengajar Ilmu Hubungan Internasional, Universitas Gadjah Mada

Hendra Nurtjahjo, 2004, Ilmu Negara Republik Indonesia(pengembangan teori bernegara dan suplemen), Pusat Studi Hukum Tata Negara.

Edi Suharto, 2006, Negara Kesejahteraan dan Reinventing Depsos, WalfareStateDeptSos.

Tavip Muhammad, 2013, Skripsi Dinamika Negara Kesejahteraan Indonesia Dalam Undang-Undang Dasar 1945: Malang: Pasca Sarjana Hukum, Universitas Brawijaya.

Nugroho, Anindya Lintang,2011, Konsep negara proporsional John Maynard Keynes sebagai dasar intervensi negara terhadap pasar,Program Studi Filsafat, Universitas Indonesia.

Asshiddiqie Jimly, Idiologi Pancasila dan Konstitusi,Mahkama Konstitusi RI. 